\title{
Deborah Brautigam, Will Africa Feed China?
}

New York, Oxford University Press, 2015, 222 pp.

\section{Étienne Monin}

\section{OpenEdition}

\section{Journals}

\section{Electronic version}

URL: http://journals.openedition.org/chinaperspectives/8300

DOI: $10.4000 /$ chinaperspectives. 8300

ISSN: 1996-4617

\section{Publisher}

Centre d'étude français sur la Chine contemporaine

\section{Printed version}

Date of publication: 1 September 2018

Number of pages: 87-88

ISSN: 2070-3449

Electronic reference

Étienne Monin, «Deborah Brautigam, Will Africa Feed China? », China Perspectives [Online], 2018/3 |

2018, Online since 01 September 2018, connection on 24 September 2020. URL : http://

journals.openedition.org/chinaperspectives/8300 ; DOI : https://doi.org/10.4000/chinaperspectives. 8300

This text was automatically generated on 24 September 2020.

(c) All rights reserved 


\section{Deborah Brautigam, Will Africa Feed China?}

New York, Oxford University Press, 2015, 222 pp.

\section{Étienne Monin}

1 Chinese farming investments in Africa have made the headlines following the 2008 global food crisis, when the global media spread reports of a foreign investment land rush in developing countries with the backing of national governments. This process, also dubbed land grab, is motivated by agroindustrial projects spread over thousands of hectares meeting not local demand but rather the markets of emerging economies or the agrofuel sectors of industrialised countries.

China has been scapegoated in polemics pitting globalised agribusiness against small peasantry. In order to "feed China," its government is said to have planned the acquisition of vast areas of African landmass for exploitation by migrant

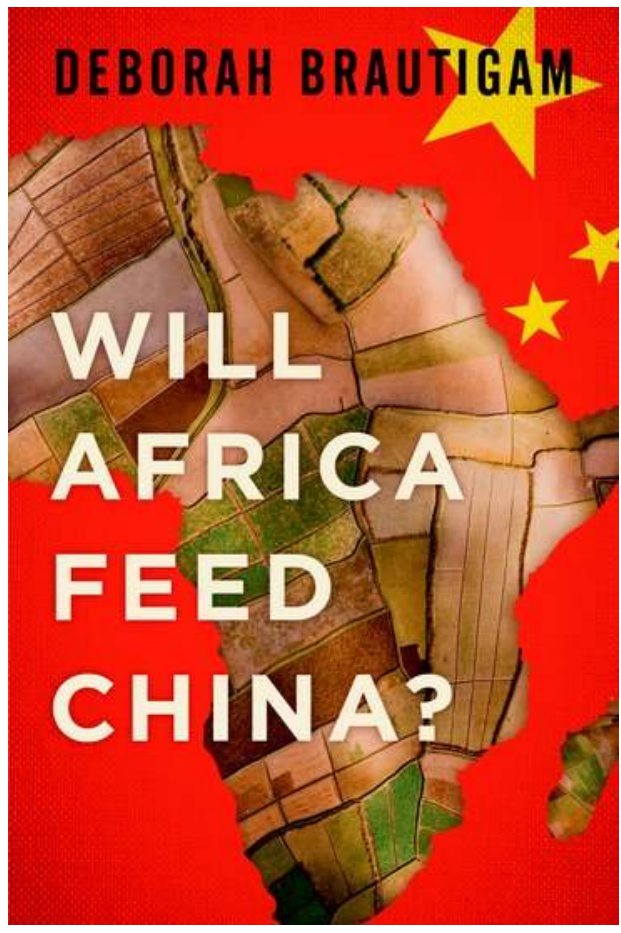
Chinese workers.

3 This caricature is countered by Deborah Brautigam, professor of political economy at Johns Hopkins University in Washington D.C. Her work discusses China's agricultural strategy in Africa and puts in perspective the challenges of food security that link them. The title, Will Africa Feed China?, is a nod to Lester Brown's Who Will Feed China? (1995) as a way of refuting a still extant Malthusian vision. The author relies on her 
own experience ${ }^{1}$ and the work of the CARI (China Africa Research Initiative) team she heads.

4 The book takes a verificatory approach, its eight chapters divided between an explanatory section (chapters 2 to 5) and accounts (chapters 1 and 6 to 8), leading the reader from Chinese landscapes to African scenes. All information on Chinese projects is subject to systematic cross-referencing through investigations among Chinese and African officials, investors, and entrepreneurs.

5 Chapter 1 exemplifies this method, sorting true from false with a case from Mozambique in 2006-the first "Chinese agricultural colony"-featuring construction of a hydroelectric dam on the Zambezi River that cost hundreds of millions of dollars. The more modest and prosaic reality illustrates Brautigam's counter-thesis: "What emerges is still (...) the story of a rising China and its companies beginning to enter global markets in helping Mozambique realize its own plans for agricultural modernization" (p. 19).

6 Chapter 2 compares recent Chinese and African farming trajectories. Net importer China has become a crucial actor in global food exchange, pursuing a selective trade policy mindful of dietary transition following urbanisation. From this viewpoint, African difficulties stem from its farmers' productive and technological lag, symbolised by cities' reliance on food imports.

7 Chinese agriculture's internationalisation, Chapter 3 shows, draws on its own agroindustrialisation process in which gradual experience has been gained over three decades. Direct investments and economic partnerships forged with foreign groups inland now serve as models for Chinese firms' global expansion.

8 The "going out" policy (zouchuqu 走出去) for investments promoted following China's accession to the WTO is described in Chapter 4, as is previous Chinese cooperation dating back to the 1960s. Public conglomerates such as China State Farm Agribusiness Corporation or China Complete Plant Import and Export Corporation benefit from the support of the Commerce and Agriculture ministries. Loans granted by the China Export Import Bank meanwhile benefit to foreign hosts.

9 What is the reality behind the expert information fuelling media reports of land grabs? Chapter 5 notes just five cases among 20 surveyed between 2000 and 2014, totalling 89,000 cultivated hectares, far short of the 5.6 million hectares cited in various reports (p. 78). ${ }^{2}$ Clearly such astonishing reports of abortive attempts and hidden failures reflect real cases of mad scrambles, shared by officials and investors worldwide.

Chapters 6 and 7 study the establishment of Chinese companies on the African continent, such as sugar factories set up in Mali and Madagascar, including malpractices, given ambiguous relations with local populations in volatile political contexts.

11 Chapter 8, the last, is prospective. Chinese agro-food capitalist expansion, subject to growing international competition, is pursuing new paths, as illustrated by agricultural demonstration centres emphasising technology transfer or the recourse to contracts with local producers, already underway in Southeast Asia.

With a clear and intelligent presentation, the book adds to Sino-African "variations" available to both specialist and lay readers. It shows Chinese "rice bowl" diplomacy as having lost its ideological edge and retreating relative to other economic domains such 
as infrastructure building or mining, now lacking also the aspect of a trading diaspora in major African cities.

The book persuasively refutes fallacies regarding Sino-African farming ties, an approach shared by other specialists. ${ }^{3}$ It stands out with rich factual elements and the diversity of situations studied-in terms of continent and country-with attention to details of stakeholders and achievements made. Tables provided in the appendix listing recent Chinese investments in Africa, agro-exports to China, and its demonstration centres complement this didactic effort.

Less convincing, perhaps, is its discursive tone, that of International Affairs mixing macroeconomic and geopolitical perspectives without detailing all ramifications. A journalistic reportage and essay style is featured, which proved successful for the book by Serge Michel and Michel Beuret, La Chinafrique. ${ }^{4}$ The analysis goes back and forth within chapters and among them, involving some repetition.

The book's critical look at media coverage and treatment of Internet sources is perfectly appropriate, but what lessons are to be drawn in the sphere of development studies, given that discussion of farming and food realities seems to be so sensitive in our societies?

This touches on the book's main limitation, more concerned as it is with narrative than with theoretical interrogations. Use of the term "developmental State" regarding the Chinese government's relations with national enterprises is problematic in view of numerous pitfalls encountered in host countries with regard to tenancy contracts, discretion left to governments, employing locals, and recourse to contractual farming (dingdan nongye 订单农业).

Comparison with agro development in China would be needed to clarify current conceptualisations of land grab amidst globalisation: the land tenure question posed as one of public ownership or collectivity, ${ }^{5}$ or global rearticulations of the capitalist food regime. ${ }^{6}$

The social experience of Chinese peasantry's modernisation could also serve as a counterpoint to revise scrutiny of alleged unscrupulousness and technicalities concerning land grab, as it can echo African countries' own aspirations to emerge as "foodocracies."

\section{NOTES}

1. See her previous book: Deborah Brautigam, The Dragon's Gift: The Real Story of China in Africa, Oxford, Oxford University Press, 2009.

2. Compare this with a Western firm such as the French group Bolloré, which acknowledged controlling 373,000 hectares of rubber and palm plantations in West Africa in the same period (p. 141).

3. For example, Jean-Jacques Gabas and Tang Xiaoyang, "Chinese Agricultural Cooperation in Sub-Saharan Africa: Challenging Preconceptions," Perspective, No. 26, Paris, CIRAD, 2014. 
4. Serge Michel and Michel Beurel, China Safari: On the Trail of Beijing's Expansion in Africa, New York, Nation Books, 2009.

5. Gérard Chouquer, "Le nouveau commerce triangulaire mondial. Ou les analogies du foncier contemporain" (New global triangular trade: Analogies of contemporary land tenure), Études rurales (Rural studies), No. 187, 2011, pp. 95-130; Li Tania Murray, “Qu'est-ce que la terre? Assemblage d'une ressource et investissement mondial" (What is land? Collection of globalised resource and investment), Tracés, Vol. 33, 2017/2, pp. 19-48.

6. Harriet Friedmann and Philip McMichael, "Agriculture and the State system: The rise and decline of national agricultures, 1870 to the present," Sociologia Ruralis, Vol. 29, No. 2, 1989, pp. 93-117.

7. Tiken Jah Fakoly, Mangercratie (Foodocracy), Paris, Louma, 1999, BS 50754.

\section{AUTHOR}

\section{ÉTIENNE MONIN}

Étienne Monin is a post-doctoral scholar in geography at the Université d'Angers

(etienne.monin@univ-angers.fr). 